\title{
Susceptibility and resistance to deltamethrin of wild and domestic populations of Triatoma infestans (Reduviidae: Triatominae) in Bolivia: new discoveries
}

\author{
Stéphanie Depickère ${ }^{1,2}{ }^{+}$, Rosio Buitrago ${ }^{1,2}$, Edda Siñani $^{2}$, Marianne Baune ${ }^{1,2}$, Marcelo Monje ${ }^{1}$, \\ Ronald Lopez ${ }^{2}$, Etienne Waleckx ${ }^{1,2}$, Tamara Chavez ${ }^{2}$, Simone Frédérique Brenière ${ }^{1,2}$ \\ ${ }^{1}$ Maladies Infectieuses et Vecteurs Écologie, Génétique, Évolution et Contrôle, Université de Montpellier 1 et 2, \\ Centre National de la Recherche Scientifique 5290, Institut de Recherche pour le Développement 224, Representation in Bolivia, \\ La Paz, Bolivia ${ }^{2}$ Laboratorio de Entomología Médica, Instituto Nacional de Laboratorios de Salud, La Paz, Bolivia
}

Bolivia is a high-endemic country for Chagas disease, for which the principal vector is Triatoma infestans (Triatominae). This is a mainly domestic species that is also found in the wild environment. Recently, an increasing number of studies have shown the importance of Triatominae resistance to insecticides, especially in Bolivia. Data regarding the susceptibility/resistance of wild and domestic populations of $\mathrm{T}$. infestans to deltamethrin are presented. For the first time, domestic populations of the department of Santa Cruz were tested, showing low resistance. Although most of the wild populations were found to be susceptible to deltamethrin, three populations from three departments showed a mortality rate of less than 100\%. This result is emphasised here.

Key words: Chagas disease - Triatoma infestans - deltamethrin - wild and domestic populations - resistance - susceptibility

Chagas disease is a major problem in Latin America, with more than 10 million infected people and 25 million at risk (WHO 2010). The pathogenic agent is a protozoan parasite, Trypanosoma cruzi, that is mainly transmitted by haematophagous bugs (Hemiptera: Reduviidae: Triatominae). Triatominae species are primarily sylvatic; some species occasionally enter dwellings by light attraction and a few species, such as Triatoma infestans, are mainly domestic, i.e., living in houses. In the absence of suitable drugs to treat patients, the control strategy for Chagas disease relies mainly on the control of the domestic vectors achieved through insecticide application in dwellings (WHO 2007). Since the 1980s, pyrethroids have been commonly used during spraying campaigns (WHO 2002); however in the last decade, Triatominae resistance to pyrethroids associated with ineffective field treatments has been reported in Rhodnius prolixus in Venezuela and in T. infestans in Brazil, Argentina and Bolivia (Vassena et al. 2000, Vassena \& Picollo 2003, Picollo et al. 2005, Alarico et al. 2010, Lardeux et al. 2010, Roca Acevedo et al. 2011).

Bolivia is a high-endemic country for Chagas disease, with $T$. infestans as the main vector. This species lives in domiciles across $60 \%$ of the territory (Petherick 2010). In recent years, the resistance of domestic $T$. infestans populations has been mapped, demonstrating

Financial support: ANR (3624), UNICEF/UNDP/World Bank/ WHO/TDR (A70596), IDRC Canada (103696-012), IRD France + Corresponding author: stephanie.depickere@gmail.com Received 13 September 2012

Accepted 6 November 2012 the broad distribution of deltamethrin resistance, with particularly high levels in the south of the country near Argentina (Alarico et al. 2010, Lardeux et al. 2010).

Added to this important problem of resistance to pyrethroids among domestic populations, $T$. infestans can no longer be considered as exclusively domestic in Bolivia. In the last few years, numerous sylvatic foci have been reported, principally in two ecoregions: Bosques Secos Interandinos and Gran Chaco (Buitrago et al. 2010, Waleckx et al. 2011, 2012). Moreover, discoveries of sylvatic foci in Argentina, Paraguay and Chile show that sylvatic populations of $T$. infestans are more widespread than initially described (Ceballos et al. 2009, Bacigalupo et al. 2010, Rolón et al. 2011). It is worth noting that these sylvatic populations have the potential to jeopardise control efforts because of possible free insect movements between the sylvatic environment and dwellings (Noireau et al. 2005, Ceballos et al. 2011). Because wild populations may recolonise insecticide-treated areas, it is extremely important to know their response to insecticides. Moreover, some complementary results of the resistance mapping of domestic populations are presented.

\section{MATERIALS AND METHODS}

Field populations - Twenty populations of T. infestans were collected from 2008-2009, including 12 from the natural environment (i.e., wild populations) and eight from villages (i.e., domestic populations). Their locations are shown in Figure and Table I. Wild populations were collected using mouse-baited adhesive traps (Noireau et al. 1999, 2002) in sites where the presence of wild triatomines was suspected. Some of the resulting data have been published describing certain biological features (Buitrago et al. 2010). Domestic populations were collected by an active search for insects during the day in the intra and peridomicile area by experienced 


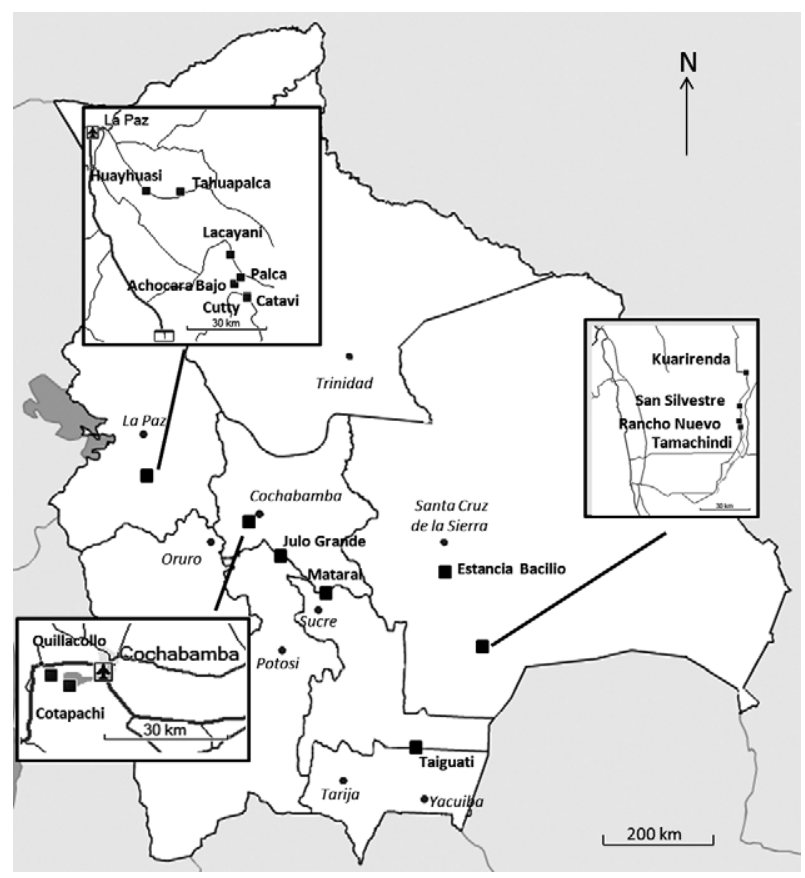

Map of Bolivia showing the departments ( $\bullet$ : main cities) and the 16 sample locations ( $\mathbf{m})$. Enlargements show the detail of the locations of the strains from the departments of La Paz, Cochabamba and Santa Cruz.

technicians. The Cutty [domestic (D)], Estancia Bacilio (D), Quillacollo (D) and Taiguati (D) populations were founded by a few bugs captured in the villages. All of these communities are under entomological surveillance by the National Chagas Control Program; therefore, these study populations can be considered to be reinfestations. Four populations [Kuarirenda (D), San Silvestre (D), Rancho Nuevo (D) and Tamachindi (D)] were collected in the Izozog region located in the driest part of the Chaco. The insects were captured during the monitoring of house reinfestation dynamics eight-20 months after insecticide spraying in all of the villages. Every four months, technicians searched for Triatominae in intra and peridomicile areas. Infested houses were then sprayed again with insecticide. Captured insects were reared in the insectary $\left[25 \pm 2^{\circ} \mathrm{C}, 65 \pm 20 \%\right.$ relative humidity (RH), 12:12 dark:light cycle]. Bioassays were performed separately on insects issued from each capture date. Due to the small number of females from each capture date, the results are presented as pooled data from the entire period. First-instar nymphs (N1) from the F1 generation were used for the bioassays. A susceptible reference strain (Picollo et al. 1976, CIPEIN CITEFA 2001) was used as a control in the bioassays.

Topical application bioassays - The deltamethrin insecticide (100\% purity, AgrEvo, Berkham, UK) diluted in acetone was topically applied $(0.2 \mu \mathrm{L}$ per insect) on the dorsal surface of the abdomen of each N1 (WHO 1994, CIPEIN CITEFA 2001) with a 10- $\mu$ L Hamilton Microliter 701 micro-syringe (Hamilton Co, Reno,
NV, USA) mounted on a repeating dispenser (Hamilton PB600). The mean weight of the nymphs was $1.74 \pm 0.28$ $\mathrm{mg}$. At least five and up to 60 insects were used per dose per replicate. Two to three replicates were performed for each population, except for Catavi and Estancia Bacilio, which had too few N1 available to repeat the test. The mortality per population was expressed as the ratio of the total number of dead bugs of all of the replicates to the total number of bugs exposed to the insecticide. The range of this mortality rate obtained in the replicates is also given. A control group that received only an application of acetone was used in each experiment. After topical applications, insects were maintained in a climatic chamber (Sanyo MLR 351-H, Japan) under controlled conditions $\left(27 \pm 1^{\circ} \mathrm{C}, 60 \pm 5 \% \mathrm{RH}, 12: 12\right.$ dark:light cycle). Mortality, defined as the inability of the N1 to walk out of a filter paper disc of $7 \mathrm{~cm}$ diameter (Vassena et al. 2000, Picollo et al. 2005), was recorded at $24 \mathrm{~h}$.

All of the populations were tested with the discriminating dose (DD) of deltamethrin determined previously on the CIPEIN-susceptible strain in our laboratory under the same conditions [DD $=5 \mathrm{ng}$ active product (active ingredient) per insect] (Lardeux et al. 2010). The DD is defined as twice the insecticide dose that kills $100 \%$ of the susceptible strain. A threshold of $80 \%$ mortality at the DD dose is usually defined to detect the presence of resistant individuals in a population (Brown \& Pal 1973). According to the nymph quantity, the value of the resistance ratio (RR) could be determined for some populations. In these experiments, at least four doses flanking the $\mathrm{LD}_{50}$ (insecticide dose that killed $50 \%$ of the population) and causing $>0$ and $<100 \%$ mortality were used. Probit analysis (Finney 1971) was performed on mortality data using PROBIT v.2 software (Raymond et al. 1993). $\mathrm{RR}$ was calculated as $\mathrm{RR}=\mathrm{LD}_{50 \text { strain }} / \mathrm{LD}_{50 \text { CIPEIN }}$.

\section{RESULTS}

Wild populations - Nine populations showed a threshold of $100 \%$ mortality at the DD dose, demonstrating their susceptibility to deltamethrin (Table II). Two populations, Achocara Bajo (98\%) and Mataral (96\%), showed a small decrease in susceptibility and a third population, Julo Grande (79\%), was resistant to deltamethrin. It is noteworthy that these three strains were collected in very distant places (Figure).

Domestic populations - Only the two Andean populations collected in peridomestic structures were susceptible to deltamethrin; the others from the Gran Chaco showed a mortality rate at the DD dose of less than $100 \%$ and two of them were frankly resistant (Table III). The first susceptible population was collected inside a dwelling in the village of Cutty, where the wild population collected near the village was also susceptible (Table II). The second susceptible population [Quillacollo (D)] corresponded to bugs collected in several peridomestic structures (piles of stones and bricks) of dwellings near the edge of the wilderness, where the wild susceptible population (Quillacollo) was captured in rock outcroppings at the edge of the habitat. Three populations of the Izozog region of the Chaco showed a mortality rate 
TABLE I

Geographical origin and description of the capture site of wild and domestic populations of Triatoma infestans

\begin{tabular}{|c|c|c|c|c|c|c|}
\hline $\begin{array}{l}\text { Department } \\
\text { (province) }\end{array}$ & Municipality & Community & $\begin{array}{l}\text { Latitude } \\
\text { (South) }\end{array}$ & $\begin{array}{l}\text { Longitude } \\
\text { (West) }\end{array}$ & $\begin{array}{l}\text { Altitude } \\
(\mathrm{m})\end{array}$ & Capture site \\
\hline \multirow[t]{3}{*}{$\begin{array}{l}\text { La Paz } \\
\text { (Murillo) }\end{array}$} & \multirow[t]{3}{*}{ Mecapaca } & Huayhuasi & $16^{\circ} 42^{\prime} 25^{\prime \prime}$ & $67^{\circ} 59^{\prime} 38^{\prime \prime}$ & 2.757 & $\begin{array}{l}\text { Small rodent burrows in prickly pear } \\
\text { culture, 30-100 m of isolated houses. }\end{array}$ \\
\hline & & Tahuapalca-A & $16^{\circ} 43^{\prime} 12^{\prime \prime}$ & $67^{\circ} 52^{\prime} 26^{\prime \prime}$ & 2.427 & $\begin{array}{l}\text { Field of prickly pears overhanging the } \\
\text { village (50-150 } \mathrm{m} \text { of houses). }\end{array}$ \\
\hline & & Tahuapalca-B & $16^{\circ} 42^{\prime} 56^{\prime \prime}$ & $67^{\circ} 52^{\prime} 14^{\prime \prime}$ & 2.459 & $\begin{array}{l}\text { Adobe wall of } 19 \text { th century barracks in } \\
\text { ruins and rocks, } 500 \mathrm{~m} \text { from the village. }\end{array}$ \\
\hline \multirow[t]{6}{*}{$\begin{array}{l}\text { La Paz } \\
\text { (Loayza) }\end{array}$} & \multirow[t]{6}{*}{ Luribay } & Lacayani & $16^{\circ} 55^{\prime} 49^{\prime \prime}$ & $67^{\circ} 41^{\prime} 33^{\prime \prime}$ & 2.182 & $\begin{array}{l}\text { Large stones at the side of the road } \\
\text { (500 } \mathrm{m} \text { from an isolated house). }\end{array}$ \\
\hline & & Palca & $17^{\circ} 00^{\prime} 30^{\prime \prime}$ & $67^{\circ} 39^{\prime} 25^{\prime \prime}$ & 2.356 & $\begin{array}{l}\text { Field of prickly pears with many rocks, } \\
30-50 \mathrm{~m} \text { from isolated houses }\end{array}$ \\
\hline & & Achocara Bajo & $17^{\circ} 01^{\prime} 55^{\prime \prime}$ & $67^{\circ} 40^{\prime} 39^{\prime \prime}$ & 2.159 & $\begin{array}{l}\text { Cliff of red earth along the road forming } \\
\text { small caves, } 90 \mathrm{~m} \text { from isolated houses. }\end{array}$ \\
\hline & & Catavi & $17^{\circ} 04^{\prime} 25^{\prime \prime}$ & $67^{\circ} 37^{\prime} 60^{\prime \prime}$ & 2.493 & $\begin{array}{l}\text { Field of prickly pears, } 50-100 \mathrm{~m} \text { from an } \\
\text { isolated church apart from the village. }\end{array}$ \\
\hline & & Cutty & $17^{\circ} 04^{\prime} 45^{\prime \prime}$ & $67^{\circ} 37^{\prime} 57^{\prime \prime}$ & 2.602 & $\begin{array}{l}\text { Rock-pile boundary walls and } \\
\text { wilderness field, } 100 \mathrm{~m} \text { from an isolated } \\
\text { house at the entrance of the village. }\end{array}$ \\
\hline & & Cutty (D) & $17^{\circ} 05^{\prime} 02^{\prime \prime}$ & $67^{\circ} 37^{\prime} 45^{\prime \prime}$ & 2.674 & Domestic (intradomicile). \\
\hline \multirow[t]{3}{*}{$\begin{array}{l}\text { Cochabamba } \\
\text { (Quillacollo) }\end{array}$} & \multirow[t]{3}{*}{ Quillacollo } & Cotapachi & $17^{\circ} 25^{\prime} 29^{\prime \prime}$ & $66^{\circ} 15^{\prime} 56^{\prime \prime}$ & 2.556 & $\begin{array}{l}\text { Rock outcrop, } 100-150 \mathrm{~m} \\
\text { from an isolated house. }\end{array}$ \\
\hline & & Quillacollo & $17^{\circ} 25^{\prime} 30^{\prime \prime}$ & $66^{\circ} 17^{\prime} 32^{\prime \prime}$ & 2.655 & $\begin{array}{l}\text { Rock outcrop, } 100-250 \mathrm{~m} \text { from first houses } \\
\text { of the periurban area of Quillacollo. }\end{array}$ \\
\hline & & Quillacollo (D) & $17^{\circ} 25^{\prime} 24^{\prime \prime}$ & $66^{\circ} 17^{\prime} 26^{\prime \prime}$ & 2.594 & Domestic (peridomicile). \\
\hline $\begin{array}{l}\text { Cochabamba } \\
\text { (Campero) }\end{array}$ & Aiquile & Mataral & $18^{\circ} 36^{\prime} 06^{\prime \prime}$ & $65^{\circ} 07^{\prime} 11^{\prime \prime}$ & 1.700 & $\begin{array}{l}\text { Scree rock, } 1 \mathrm{~km} \\
\text { from the village of Mataral. }\end{array}$ \\
\hline $\begin{array}{l}\text { Potosi } \\
\text { (Charcas) }\end{array}$ & Toro Toro & Julo Grande & $18^{\circ} 01^{\prime} 51^{\prime \prime}$ & $65^{\circ} 47^{\prime} 19^{\prime \prime}$ & 1.993 & $\begin{array}{l}\text { Rocky cliff } 15 \mathrm{~m} \text { high, } 200 \mathrm{~m} \\
\text { from the village. }\end{array}$ \\
\hline $\begin{array}{l}\text { Santa Cruz } \\
\text { (Andrés Ibañez) }\end{array}$ & La Guardia & Estancia Bacilio (D) & $18^{\circ} 07^{\prime} 17^{\prime \prime}$ & $63^{\circ} 11^{\prime} 39^{\prime \prime}$ & 500 & Domestic (peridomicile). \\
\hline \multirow{4}{*}{$\begin{array}{l}\text { Santa Cruz } \\
\text { (Cordillera) }\end{array}$} & \multirow[t]{4}{*}{ Charagua } & Kuarirenda (D) & $19^{\circ} 10^{\prime} 38^{\prime \prime}$ & $62^{\circ} 31^{\prime} 36^{\prime \prime}$ & 375 & Domestic (intra and peridomicile). \\
\hline & & San Silvestre (D) & $19^{\circ} 21^{\prime} 21^{\prime \prime}$ & $62^{\circ} 34^{\prime} 10^{\prime \prime}$ & 400 & Domestic (intra and peridomicile). \\
\hline & & Rancho Nuevo (D) & $19^{\circ} 26^{\prime} 22^{\prime \prime}$ & $62^{\circ} 34^{\prime} 05^{\prime \prime}$ & 410 & Domestic (intra and peridomicile). \\
\hline & & Tamachindi (D) & $19^{\circ} 28^{\prime} 41^{\prime \prime}$ & $62^{\circ} 33^{\prime} 49^{\prime \prime}$ & 410 & Domestic (intra and peridomicile). \\
\hline $\begin{array}{l}\text { Tarija } \\
\text { (Gran Chaco) }\end{array}$ & Villamontes & Taiguati (D) & $21^{\circ} 09^{\prime} 02^{\prime \prime}$ & $63^{\circ} 21^{\prime} 56^{\prime \prime}$ & 463 & Domestic (peridomicile). \\
\hline
\end{tabular}

of between $80-100 \%$ at the DD dose. The last population of this region was resistant. The RR index of these populations ranged from 3.8-8.3. The two other populations were collected farther north [Estancia Bacilio (D)] and south [Taiguati (D)] of the four villages and were from chicken coops. The Estancia Bacilio population also showed a small decrease in mortality rate and the Taiguati population was the most resistant $(\mathrm{RR}=818)$.

\section{DISCUSSION}

Previous data showed that resistance of domestic $T$. infestans to deltamethrin is widespread, high in Argentina (Vassena \& Picollo 2003, Audino et al. 2004) and particularly high in Bolivia, where the highest levels of resistance were observed in the department of Tarija
(Alarico et al. 2010, Germano et al. 2010, Lardeux et al. 2010). The present results confirmed this tendency, with the highest RR observed in the domestic population of Taiguati $(\mathrm{RR}=818)$, a colony of approximately 25 specimens collected in a henhouse. For the first time, five populations of domestic T. infestans in the department of Santa Cruz were studied using the same protocol as Lardeux et al. (2010). These populations showed a mean mortality rate at a DD of $85.2 \pm 8.1 \%$ and a mean RR of $6.8 \pm 2.6$. Compared with other Bolivian departmental results (Lardeux et al. 2010), Santa Cruz is currently the department where $T$. infestans populations are the most susceptible to deltamethrin. It is noteworthy that the populations from the Izozog region were captured in intra and peridomicile areas eight- 20 months after insec- 
ticide spraying in all of the villages during a study to investigate house-reinfestation dynamics. Genetic analysis of these bugs showed that they most likely originated from treatment survivors (Quisberth et al. 2011). The occurrence of a low level of resistance to deltamethrin in these populations most likely plays a role in the per-

\section{TABLE II}

Toxicity of topically applied deltamethrin to Bolivian Triatoma infestans wild populations

\begin{tabular}{lc}
\hline Population & $\begin{array}{c}\text { Mortality at DD }(\%) \\
\text { (insect number)/(range between replicates) }\end{array}$ \\
\hline Achocara Bajo Catavi $^{a}$ & $98(58) /(96-100)$ \\
Cotapachi & $100(9) /(-)$ \\
Cutty & $100(46) /(100-100)$ \\
Huayhuasi & $100(49) /(100-100)$ \\
Julo Grande & $100(52) /(100-100)$ \\
Lacayani & $79(85) /(47-94)$ \\
Mataral & $100(43) /(100-100)$ \\
Palca & $96(56) /(90-100)$ \\
Quillacollo & $100(42) /(100-100)$ \\
Tahuapalca-A & $100(80) /(100-100)$ \\
Tahuapalca-B & $100(32) /(100-100)$ \\
\hline
\end{tabular}

$a$ : just one replicate; DD: discriminating dose. sistence of the reinfestation that was observed during the entire monitoring period (2008-2009). Interestingly, we observed a tendency towards a higher mortality rate with the time elapsed since the initial insecticide spraying, showing that the susceptibility of the population trended upwards when the insecticide pressure decreased. Resistance is not likely the only factor leading to the very rapid and intense reinfestation in these villages (unpublished observations).

A wide range of Andean wild populations of $T$. infestans were analysed for their resistance to deltamethrin. Indeed, wild populations that can migrate to human habitats can be resistant to this insecticide and the risk that these populations will colonise the human habitat is of great concern because they belong to a species that previously successfully adapted to human habitats. For now, most of these populations (8/11) were susceptible to deltamethrin, with a mortality rate of $100 \%$. In Cutty (La Paz) and in Quillacollo (Cochabamba), wild and domestic populations were both observed to be susceptible to deltamethrin. A wild population from Potosi was determined to be resistant, with a mortality rate of $79 \%$ at the discriminating dose. This colony's collection site was located in the same municipality as the wild Kirus Mayu strain previously reported to be resistant to deltamethrin by Roca Acevedo et al. (2011). Two other populations, one from La Paz and the other from Cochabamba, also showed a slight decrease in mortality rate at the DD (Achocara Bajo: 98\%; Mataral: 96\%).

TABLE III

Toxicity of topically applied deltamethrin to Bolivian Triatoma infestans domestic populations

Probit line

\begin{tabular}{|c|c|c|c|c|c|c|}
\hline Populations & $\begin{array}{c}\text { Mortality at DD (\%) } \\
\text { (insect number)// } \\
\text { (range between replicates) }\end{array}$ & $\begin{array}{l}\text { Tested } \\
\text { insects } \\
\text { (n) }\end{array}$ & $\begin{array}{c}\text { Slope } \\
\text { (standard error) }\end{array}$ & $\mathrm{Chi}^{2}(\mathrm{df}) \mathrm{p}$ & $\mathrm{LD}_{50}(95 \% \mathrm{CI})$ & $\mathrm{RR}(95 \% \mathrm{CI})$ \\
\hline $\begin{array}{l}\text { CIPEIN } \\
\text { (susceptible } \\
\text { laboratory strain) }{ }^{a}\end{array}$ & 100 & 739 & $2.73(0.21)$ & 1.29 (4) 0.86 & $0.24(0.22-0.26)$ & - \\
\hline Cutty (D) & $100(37) /(100-100)$ & - & - & - & - & - \\
\hline Estancia Bacilio (D) ${ }^{b}$ & $88(26) /(-)$ & - & - & - & - & - \\
\hline Kuarirenda (D) & $94(154) /(90-100)$ & 203 & $3.34(0.16)$ & 1.37 (3) 0.71 & $0.91(0.00-1.71)$ & $3.80(0.00-6.58)$ \\
\hline Quillacollo (D) & $100(104) /(100-100)$ & - & - & - & - & - \\
\hline Rancho Nuevo (D) & $80(306) /(51-89)$ & 274 & $3.53(0.10)$ & 0.99 (3) 0.80 & $1.98(1.78-2.24)$ & $8.25(8.09-8.61)$ \\
\hline San Silvestre (D) & $74(117) /(70-89)$ & 213 & $4.21(0.03)$ & 0.08 (3) 0.99 & $1.99(0.77-2.45)$ & $8.29(3.50-9.42)$ \\
\hline Taiguati (D) & $0(25) /(-)$ & 328 & $3.41(0.36)$ & 5.36 (3) 0.15 & $196.38(166.95-262.60)$ & $818(758-1010)$ \\
\hline Tamachindi (D) & $90(150) /(75-96)$ & - & - & - & - & - \\
\hline
\end{tabular}

$a$ : results from Lardeux et al. (2010); $b$ : just one replicate; D: domestic; DD: discriminating dose (number of tested first-instar nymphs); df: degrees of freedom. Insecticide dose that killed $50 \%$ of the population $\left(\mathrm{LD}_{50}\right)$ and resistance ratio (RR) (relative to CIPEIN strain) are expressed with the $95 \%$ confidence interval (CI) in parenthesis. 
Why did some wild strains show resistance to deltamethrin? At least three hypotheses can be put forward: (i) the existence of natural resistance in wild populations, (ii) resistance developed by contact with insecticides used in agriculture and/or in malaria control and (iii) the existence of a contact between these populations and resistant populations of a nearby village. The presence of natural resistance to deltamethrin in Triatominae has never been demonstrated and most of our wild strains were susceptible to deltamethrin, including some domestic populations of T. infestans (Sonoda et al. 2009, Lardeux et al. 2010). Nevertheless, Roca Acevedo et al. (2011) hypothesised that wild populations of T. infestans from different geographical areas would have different toxicological profiles. Because deltamethrin is also used as an insecticide in agriculture in Bolivia (R Cortez, unpublished observations), the second hypothesis may be an explanation in the Achocara Bajo and Julo Grande populations because of the presence of farmland in the vicinity of the capture sites. Nevertheless, in Mataral, the insects were captured in rocks $2 \mathrm{~km}$ from the village with no surrounding farmland. This result confirms the previous result obtained from a strain collected one year before at the same site (Roca Acevedo et al. 2011). Finally, contact between wild and domestic populations may occur in the three sites because of their location near paths where inhabitants pass through with their domestic animals (e.g., goats and cows). Although no information is available on the domestic populations of $T$. infestans in Achocara Bajo or Julo Grande, the resistance of domestic T. infestans in Mataral is well established and higher than in the current wild population $(67 \%$ mortality) (Lardeux et al. 2010). The flow of insects between sylvatic and domestic habitat is of great importance in vector control because sylvatic populations can be a source of reinfestation of dwellings and are more widespread than was previously thought. Ceballos et al. (2011) showed that some T. infestans wild colonies were closely connected to domestic conspecifics in the Argentinean Chaco and that sylvatic habitats may provide a transient or permanent refuge after control interventions, functioning as sources for domestic/peridomestic reinfestation. Given the possible large numbers of wild populations in the dwelling-reinfestation process, it is imperative that we fully understand the origin of the resistance to insecticide observed in wild populations of T. infestans and more accurately measure the flow of insects between wild and domestic foci through further genetic analyses and behavioural studies.

\section{ACKNOWLEDGEMENTS}

To Marie-France Bosseno (IRD) and the Santa Cruz SEDES team of technical workers, for their assistance in field work.

\section{REFERENCES}

Alarico AG, Romero N, Hernández L, Catalá S, Gorla D 2010. Residual effect of a micro-encapsulated formulation of organophosphates and piriproxifen on the mortality of deltamethrin resistant Triatoma infestans populations in rural houses of the Bolivian Chaco region. Mem Inst Oswaldo Cruz 105: 752-756.

Audino PG, Vassena C, Barrios S, Zerba E, Picollo MI 2004. Role of enhanced detoxication in a deltamethrin-resistant population of Triatoma infestans (Hemiptera, Reduviidae) from Argentina. Mem Inst Oswaldo Cruz 99: 335-339.

Bacigalupo A, Torres-Pérez F, Segovia V, García A, Correa JP, Moreno L, Arroyo P, Cattan PE 2010. Sylvatic foci of the Chagas disease vector Triatoma infestans in Chile: description of a new focus and challenges for control programs. Mem Inst Oswaldo Cruz 105: 633-641.

Brown AWA, Pal R 1973. Résistance des arthropodes aux insecticides, 2nd ed., Série de Monographies 38, Organisation Mondiale de la Santé, Geneve, 541 pp.

Buitrago R, Waleckx E, Bosseno MF, Zoveda F, Vidaurre P, Salas R, Mamani E, Noireau F, Brenière SF 2010. First report of widespread wild populations of Triatoma infestans (Reduviidae, Triatominae) in the valleys of La Paz, Bolivia. Am J Trop Med Hyg 82: 574-579.

Ceballos LA, Piccinali RV, Berkunsky I, Kitron U, Gürtler RE 2009. First finding of melanic sylvatic Triatoma infestans (Hemiptera: Reduviidae) colonies in the Argentine Chaco. J Med Entomol 46: 1195-1202.

Ceballos LA, Piccinali RV, Marcet PL, Vazquez-Prokopec GM, Cardinal MV, Schachter-Broide J, Dujardin JP, Dotson EM, Kitron U, Gürtler RE 2011. Hidden sylvatic foci of the main vector of Chagas disease Triatoma infestans: threats to the vector elimination campaign? PLoS Negl Trop Dis 5: e1365.

CIPEIN CITEFA - Centro de Investigaciones de Plagas e Insecticidas 2001. Protocolo de evaluación de efecto insecticida en Triatoma infestans. In Relcot, Monitoreo de la resistencia a insecticidas en triatominos en América Latina, Fundación Mundo Sano, Buenos Aires, p. 53-59.

Finney DJ 1971. Probit analysis, 3rd ed., Cambridge University Press, Cambridge, 333 pp.

Germano MD, Roca Acevedo G, Mougabure Cueto GA, Toloza AC, Vassena CV, Picollo MI 2010. New findings of insecticide resistance in Triatoma infestans (Heteroptera: Reduviidae) from the Gran Chaco. J Med Entomol 47: 1077-1081.

Lardeux F, Depickère S, Duchon S, Chavez T 2010. Insecticide resistance of Triatoma infestans (Hemiptera, Reduviidae) vector of Chagas disease in Bolivia. Trop Med Int Health 15: 1037-1048.

Noireau F, Abad-Franch F, Valente SAS, Dias-Lima A, Lopes CM, Cunha V, Valente VC, Palomeque FS, de Carvalho-Pinto CJ, Sherlock I, Aguilar M, Steindel M, Grisard EC, Jurberg J 2002. Trapping Triatominae in silvatic habitats. Mem Inst Oswaldo Cruz 97: 61-63.

Noireau F, Flores R, Vargas F 1999. Trapping sylvatic Triatominae (Reduviidae) in 210 hollow trees. Trans $R$ Soc Trop Med Hyg 93: 13-14.

Noireau F, Rojas Cortéz MG, Monteiro FA, Jansen AM, Torrico F 2005. Can wild Triatoma infestans foci in Bolivia jeopardize Chagas disease control efforts? Trends Parasitol 21: 7-10.

Petherick A 2010. Country by country. Nature 465: 10-11.

Picollo MI, Vassena CV, Santo Orihuela P, Barrios S, Zaidemberg M, Zerba EN 2005. High resistance to pyrethroid insecticides associated with ineffective field treatments in Triatoma infestans (Hemiptera: Reduviidae) from Northern Argentina. J Med Entomol 42: 637-642.

Picollo MI, Wood E, Zerba E, Licastro SA, Ruveda MA 1976. Métodos de laboratorio para medir la actividad de insecticidas en Triatoma infestans. Acta Bioquim Clin Latinoam 10: 67-71.

Quisberth S, Waleckx E, Monje M, Chang B, Noireau F, Brenière SF 2011. "Andean" and "non-Andean" ITS-2 and mtCytB haplo- 
types of Triatoma infestans are observed in the Gran Chaco (Bolivia): population genetics and the origin of reinfestation. Infect Genet Evol 11: 1006-1014.

Raymond M, Prato G, Ratsira D 1993. PROBIT analysis of mortality assays displaying quantal response, version 3.3. Praxème Sarl, St. Georges d'Orques, France.

Roca Acevedo G, Mougabure Cueto G, Germano M, Santo Orihuela P, Rojas Cortez M, Noireau F, Picollo MI, Vassena C 2011. Susceptibility of sylvatic Triatoma infestans from Andean valleys of Bolivia to deltamethrin and fipronil. J Med Entomol 48: 828-835.

Rolón M, Vega MC, Román F, Gómez A, de Arias AR 2011. First report of colonies of sylvatic Triatoma infestans (Hemiptera: Reduviidae) in the Paraguayan Chaco, using a trained dog. PLoS Negl Trop Dis 5: e1026.

Sonoda IV, Pessoa GCD, Cortez MR, Dias JCP, Romanha AJ, Diotaiuti L 2009. Susceptibility of Triatoma infestans to deltamethrin in Rio Grande do Sul, Brazil. Mem Inst Oswaldo Cruz 104: 668-670.

Vassena CV, Picollo MI 2003. Monitoreo de resistencia a insecticidas en poblaciones de campo de Triatoma infestans y Rhodnius prolixus, insectos vectores de la enfermedad de Chagas. Retel 3: 21.

Vassena CV, Picollo MI, Zerba EN 2000. Insecticide resistance in
Brazilian Triatoma infestans and Venezuelan Rhodnius prolixus. Med Vet Entomol 14: 51-55.

Waleckx E, Depickère S, Salas R, Aliaga C, Monje M, Calle H, Buitrago R, Noireau F, Brenière SF 2012. New discoveries of sylvatic Triatoma infestans (Hemiptera: Reduviidae) throughout the Bolivian Chaco. Am J Trop Med Hyg 86: 455-458.

Waleckx E, Salas R, Huamán N, Buitrago R, Bosseno MF, Aliaga C, Barnabé C, Rodriguez R, Zoveda F, Monje M, Baune M, Quisberth S, Villena E, Kengne P, Noireau F, Brenière SF 2011. New insights on the Chagas disease main vector Triatoma infestans (Reduviidae, Triatominae) brought by the genetic analysis of Bolivian sylvatic populations. Infect Genet Evol 11: 1045-1057.

WHO - World Health Organization 1994. Protocolo de evaluación de efecto insecticida sobre Triatominos. Acta Toxicol Argentina 2: 29-32.

WHO - World Health Organization 2002. Control of Chagas disease. WHO Tech Rep Ser 905: 109.

WHO - World Health Organization 2007. Report of scientific group in Chagas disease. Available from: who.int/tdr/publications/tdrresearch-publications/reporte-enfermedad-chagas/en/.

WHO - World Health Organization 2010. Chagas disease (American trypanosomiasis). Available from: who.int/mediacentre/factsheets/fs340/en/index.html. 